\title{
Explanační principy ve studiu kolektivní paměti: Kultura, kognice a jejich situovanost*
}

\author{
TOMÁŠ KARGER** \\ Explanatory Principles in Research of Collective Memory: Culture, Cognition \\ and their Situatedness
}

\begin{abstract}
Research addressing collective memory in the Czech context is predominantly based on the constructivist approach laid out by Maurice Halbwachs. This approach can be characterized by an assumption of omnipresent existence of stable structures of meaning with which action is explained. In the existing literature, we can also find alternative approaches based on findings of the cognitive sciences. These approaches can be characterized by searching for neurophysiological invariants which determine the diffusion of cultural representations. With respect to this state of the research field, the aim of this text is twofold. First, to demonstrate that the assumptions highlighting supra-individual semantic structures introduced by the Halbwachsian tradition lead to premature closure of explanation, without taking into account the question of diffusion of semantic structures. Second, to show that the focus on cognitive phenomena (taking into account the question of diffusion of semantic structures) does not have to lead to acceptance of reductionist premises. As a result, this study attempts to suggest an approach which would be able to study collective memory without reliance on supra-individual entities on the one hand and on reductionist assumptions on the other. It seems that the approach of Situational Analysis fits those criteria well and therefore it is introduced in the concluding parts of the text.
\end{abstract}

Keywords: Collective memory; Religious memory; Actor-network theory; Distributed cognition; Explanatory principles; Situational analysis

DOI: $10.14712 / 23363525.2017 .37$

\section{Úvod}

Výzkumu kolektivní paměti se v současné době věnuje mnoho badatelů v České republice i v zahraničí. Jde také o pole bádání, které není jednoznačně vymezeno ve vztahu $\mathrm{k}$ existujícím oborům. Relevantní v tomto ohledu nejsou jen sociologie a historie (či historická sociologie), ale - jak uvidíme - např́klad i kognitivní vědy. $Z$ tohoto pohledu se pak může zdát překvapivé, že obvykle podávaná vysvětlení fenoménů vztahujících se ke kolektivní paměti mají v určitém smyslu homogenní povahu. Tato společná tendence se projevuje selektivním zaměřením bádání na určitý typ empirického materiálu a nezohledňováním působení typů jiných. Cílem tohoto textu je poukázat na zmíněnou společnou tendenci ve vysvětlování jevů kolektivní paměti, zvážit limitace, jež jsou s touto tendencí spojeny, a navrhnout alternativní př́stup, který by se těmto limitacím mohl vyhnout.

\footnotetext{
" Tento text vznikl v rámci řešení výzkumného projektu podpořeného Grantovou agenturou České republiky (GAČR P404 14-01948S).

** Tomáš Karger, Ph.D., Centrum výzkumu, Univerzita Tomáše Bati ve Zlíně, nám. T. G. Masaryka 1279, 76001 Zlín. E-mail: karger@fhs.utb.cz.
} 
Konkrétněji řečeno, tato stat’ se zabývá východisky zkoumání a na ně navazujícími způsoby vysvětlování kolektivní paměti v českém kontextu. Studie zabývající se kolektivní pamětí se povětšinou zakládají na východiscích, jejichž původcem je Maurice Halbwachs [1992]. Takové přebírání tezí dnes už klasického autora a následovníka Emila Durkheima ${ }^{1}$ však má důsledky pro způsoby vysvětlování pozorovaných jevů, které autoři jednotlivých studií používají. Většinou dochází k přisuzování determinující pozice některé z nadindividuálních významových struktur, jako jsou sociální rámce interpretace nebo kolektivní pamět samotná. Otázka šíření těchto významových struktur ale zůstává většinou nepovšimnuta. $\mathrm{V}$ českém prostředí nabízí alternativu vưči tomuto přístupu Dušan Lužný [2014], který argumentuje pro příklon ke kognitivním neurovědám, jež by mohly šíření významových struktur s ohledem na vlastnosti lidské kognice vysvětlit. Tento přístup však má tendenci redukovat kolektivní pamět na úroveň biologických jevů. V tomto textu se pokusím kriticky zhodnotit oba přístupy a nastínit přístup třetí, který na jedné straně nemá tendenci předpokládat všudypřítomnost významových struktur a na straně druhé netíhne k redukcionismu, jímž se vyznačují obory, o kterých píše Lužný.

Ambicí této studie však není navrhnout přístup ke zkoumání kolektivní paměti, který by nahradil ty stávající (případně jiné navrhované), ale poukázat na oblast, která je v současných studiích často opomíjena, a tím pole bádání rozšírit. V pozadí tohoto pokusu stojí poměrně jednoduchá premisa: pokud budeme kolektivní pamět nahlížet jako určitý typ vědění vztahující se $\mathrm{k}$ minulosti, mohli bychom k jejímu zkoumání využít přístupy, které se při zkoumání vědění v jiných oblastech, jak se zdá, již osvědčily. Jak bude $\mathrm{z}$ dalších odstavců patrné, za reprezentanta takových prrístupů považuji především Actor-Network Theory [Latour 2005], doplněnou o základní teze teorie distribuované kognice [Hutchins 1995]. Jako integrující přístup v rovině teoretické a metodologické pak v závěru představím př́stup situační analýzy Adele Clarke [2003, 2005].

\section{Kulturně orientované př́istupy ve zkoumání kolektivní paměti}

Již v roce 1999 rozlišil Jeffrey Olick [1999] ve zkoumání kolektivní paměti dvě tradice. První z nich, označovanou jako „shromážděnou pamět“ (collected memory), charakterizuje spoléháním na východiska metodologického individualismu a z nich vycházející tezi, že pamětí může disponovat pouze jednotlivec. Tato východiska pak vedou k uplatňování výzkumných strategií, které se zaměřují na sbírání individuálních výpovědí a jejich agregaci [Olick 1999: 338]. Druhou z nich, kolektivní pamět' (collective memory), charakterizuje jako zohledňující skutečnost, že některé jevy nejsou redukovatelné na agregaci individuálních projevů. To se týká především symbolických systémů, jež vykazují určitou autonomii na individuálním jednání [Olick 1999: 341]. V následujícím textu se budu věnovat projevům obou těchto kultur v českém prostředí, přičemž začnu druhou $\mathrm{z}$ nich.

V mnoha studiích publikovaných v českých časopisech můžeme najít kolektivní pamět definovanou jako soubor reprezentací minulosti, které jsou založeny na sociálních rámcích, jež jsou svázány s určitou skupinou svých nositelů. Charakteristickým rysem takových př́stupů je, že kolektivní pamět nebo sociální rámce v jejich východiscích vystupují jako významové struktury, tedy jako určitý typ nadindividuálních entit v durkheimovském

1 Durkheimův vliv na Halbwachsovo myšlení popsal např́ílad Jiří Šubrt [2011, 2014: 25]. 
smyslu. Tato tendence může v některých případech vést až ke smazávání hranice mezi pojmy „kolektivní pamět“ a „kultura“, což je důsledek, který je v zahraniční literatuře podrobován kritické diskuzi [Kapusta 2013: 78]. Autoři pak často předpokládají, že se v těchto významových strukturách bude nacházet odůvodnění sociálního jednání, a tak své bádání orientují na jejich obsah. Jsou to tedy většinou entity, definované durkheimovskou tradicí, jež stojí v pozadí jednání a umožňují ho vysvětlit.

Tuto tendenci bychom mohli podobně jako např́iklad Eva Šlesingerová [2010: 45] zarámovat jako dualitu aktéra a struktury a konstatovat, že celkový jev je nutné vnímat jako „souhru“ těchto dvou rovin [Šlesingerová 2010: 55]. Cílená vyváženost této perspektivy je však narušována odlišným postavením, jež se těmto rovinám ve studiích zpravidla dostává. Svá tvrzení se pokusím ilustrovat na studii Gábora Oláha Kolektivní pamět, prostor a významy. Př́pad náměstí Svobody v Budapešti [2013], ve které jsou explicitně formulovány předpoklady, jež můžeme v ostatních studiích najít spíše implicitně. Prostřednictvím odkazů $\mathrm{k}$ dalším studiím se přitom pokusím naznačit rozšířenost pozorované tendence. ${ }^{2}$

Studie Gábora Oláha se v teoretické rovině zakládá na př́istupu kulturní sociologie, jejíž ústřední postavou je Jeffrey Alexander. Tento autor může být nahlížen jako pokračovatel tradice myšlení, která sahá od definování společenských faktů jako reality sui generis Émilem Durkheimem [1969: 42] přes hodnoty na vrcholu kybernetické hierarchie Talcotta Parsonse [1971: 168-69] právě k tezi o autonomii kultury, kterou Oláh [2013: 730] od Alexandra [například Reed - Alexander 2009: 30] přebírá. Smysl této teze pak Oláh vidí v tom, že umožňuje analyticky oddělit kulturu od zbytku sociální struktury a zkoumat tak sílu, jež formuje kontext a orientuje jednání. V důsledku pak tento přístup přivádí Oláha k tvrzení, že „smysl kulturní autonomie spočívá v tom, že pomocí kultury je možné vysvětlit události“ [Oláh 2013: 734]. ${ }^{3}$

Substrát, z něhož se kultura sestává, pak tvoří „významy“, jimž Oláh přisuzuje „sílu“ při formování praktik vzpomínání [Oláh 2013: 731]. Tyto významy jsou sdíleny nositelskými skupinami, mezi nimiž se mohou prolínat, ale které mohou také vůči sobě navzájem polarizovat (což je případ, který Oláh zkoumá). Podle tohoto autora také některé významy nabývají ikonického charakteru tím, že jsou materiálně ztvárněny, např́íklad do podoby památníku nebo sochy. Tyto významy pak jsou schopny motivovat jednání nejen v kognitivní rovině, ale i v rovině senzuální a estetické [Oláh 2013: 731]. To podle Oláha jen posiluje pozici kultury při vysvětlování zkoumaných událostí. ${ }^{4}$ Mohlo by se zdát, že materiální

2 Zde je také nutná poznámka, že u uváděných studií nemám v úmyslu zpochybňovat jejich empirická zjištění. Jde mi hlavně o načrtnutí toho, co považuji za standardní východiska a na ně navazující zpusob vysvětlování jevů v oblasti studia kolektivní paměti v České republice.

3 V teoretické rovině se Alexandrově tezi o autonomii kultury podrobně věnuje Marek Skovajsa [2014]. Tato studie se však zaměřuje na uchopení důsledků, které tato teze má v empirickém výzkumu.

4 Podobná východiska, byt' ne tak podrobně rozpracovaná, můžeme najít v dalších studiích zkoumajících kolektivní pamět. Již název studie Blanky Markové a Ondřeje Šlacha explicitně říká, že kultura „táhne“ urbánní regeneraci [Marková - Šlach 2013]. Opět se jedná o uplatnění předpokladu kultury jakožto „síly“, jež nějakým způsobem ovlivňuje sociální dění. Analogicky vystupuje koncept „kolektivních rámcü“ve studii Olgy Šmídové [2010], kde v souladu s klasickým halbwachsovským modelem předkládá sdílené představy, jež zakládají reálnost individuální paměti. Ve studii Gergely Kunta a kolektivu [Kunt - Szeg - Vajda 2013], jež se v rámci mad’arského veřejného prostoru zabývá ústředním sporem o výklad klíčových událostí dvacátého století, dále nacházíme „interpretace“, jež hrají podobnou roli jako „významy“ ve studii Gábora Oláha. Analogické se pak zdá být užívání pojmu „reprezentace“ ve studii Petry Burzové a kol. [Burzová a kol. 2013], která se snaží zachytit vzpomínání obyvatel již převážně neexistujícího městského prostoru. 
objekty (případně místa) hrají ve zkoumání kolektivní paměti významnou roli. Konečně, Lužný shrnuje tuto tendenci a poukazuje na její zakotvení u klasických teoretiků paměti následovně:

Kulturní pamět je vždy objektivovaná (ztělesněná) v nějakých materiálních entitách a přenesená do prostoru. Existuje vždy mnemotop (Halbwachs, Assmann), něco, co slouží jako nástroj připomínání, resp. předávání a rekonstruování paměti. Vždy je možné identifikovat „místa paměti“ (Norra) či „krajiny vzpomínáni“ (Assmann) [Lužný 2014: 9].

Krátký exkurz do studie Gábora Oláha nám však ukáže, že takové objekty zde zpravidla vystupují v jedné předem připravené roli. Oláh již na prvních stranách své studie dává do souvislosti tezi o autonomii kultury s badatelským zájmem o sochy a památníky [Oláh 2013: 730]. To proto, že významy, z nichž kultura sestává, se podle něj „materializují v sochách a památnících“ [Oláh 2013: 734] a tím získávají „ikonický charakter“ [Oláh 2013: 731], jenž dále posiluje jejich vliv. Tomuto přístupu k materiálním objektům pak opět odpovídají závěry studie, kde tyto objekty vystupují v roli jakýchsi materiálních kotev, které drží významy na určitém místě (byt je podle Oláha kolektivní pamět schopna udržet významy v prostoru i bez materiálního zakotvení) [Oláh 2013: 747].5 6

Je zřejmé, že zde materiální objekty vystupují především v roli pasivních povrchů reflektujících zkoumané významy. Tyto objekty jsou hmatatelnými (či obyvatelnými) symboly a jako takové mají být i čteny a interpretovány. Takový přístup je odpovídající v prrípadech památníků, které za účelem symbolizace přímo vznikají - jak poznamenává například Eduard Maur [2014: 151]. Současně ale toto zaměření vede k zúžení selekce objektů, jež bývají do zkoumání zahrnuty, čímž se také zužuje horizont zkoumatelných jevů. Tuto tendenci můžeme pozorovat jak ve vztahu k objektům, které by měly „kotvit“ významy v prostoru (jako jsou např́iklad budovy či jiné architektonické struktury), tak ve vztahu $\mathrm{k}$ objektům, jež by měly významům umožňovat prostor překonávat - $\mathrm{k}$ médiím.

Jak jsme viděli výše, první typ objektů je často nahlížen pouze s ohledem na ikonický charakter, kterým disponují pro posilování jednoho typu významů. V zahraniční literatuře však nacházíme autory, kteří takové nazírání na objekty podrobují kritice. Např́klad Michael Guggenheim poukazuje na to, že budovy a místa nelze podrobit kontrole ve formě izolace od prostředí (tak jako tomu bývá například u exponátů vystavených v muzeu) [Guggenheim 2009: 45]. Podle Guggenheima se pak v tomto typu objektů současně prolínají různé účely a způsoby užívání, které mohou mnohdy nabývat i konfliktního charakteru (např́íklad když se rozhoduje o opravách, které by měly zachovat funkčnost budovy,

\footnotetext{
Podobným způsobem např́klad Burzová a kol. nakládají s objekty, jako jsou domy, části ulic nebo bývalého parku, které „reprezentuji“ určitý pohled na svět [Burzová a kol. 2013: 122].

6 Podobnou tendenci je možné najít v závěru kolektivní monografie věnující se kolektivní paměti, již editovali Jiří Šubrt a Nicolas Maslowski [2014]. Na jedné straně se zde může čtenář dočíst, že „otázka nosičů a médií je v úvahách o kolektivní paměti všudypřítomná“ [Maslowski - Šubrt 2014: 277]. Hned v následujícím odstavci jsou ale zprostředkovatelé kolektivní paměti podřízeni významovým strukturám: „Člověku umožňuje pracovat $\mathrm{s}$ informacemi uloženými na těchto nosičích především to, co je v lidském vědomí označováno jako smysl (ve weberovském pojetí tohoto pojmu). Smysl představuje jakýsi ,operační modus', který umožňuje organizovat a interpretovat obsahy paměti, hierarchizovat je a provádět jejich nutnou selekci. Utváření tohoto smyslu je záležitostí socializačního procesu a může se stát také předmětem manipulace nebo morálního boje“ [Maslowski - Šubrt 2014: 277].
} 
ale zároveň by mohly narušit autenticitu jejího původního stavu) [Guggenheim 2009: 46]. Nahližet na budovy pouze jako na materiální kotvy připisovaného významu pak představuje určitou redukci. ${ }^{7}$

Druhý typ objektů, média zprostředkovávající významy, je v českých výzkumech kolektivní paměti často opomíjen. Spíše je přijímán předpoklad, že kulturní významy jsou aktérům všeobecně přístupné. Výjimku v této tendenci v poslední době tvoří dva výzkumy, které informační zdroje ve svém designu zohlednily. Jedná se zaprvé o výzkum Jiř́ho Šubrta a jeho týmu [Šubrt - Vinopal 2013; Šubrt - Vinopal - Vávra 2013], který identifikuje informační zdroje, jež jsou respondenty nejčastěji používány k získávání informací o minulosti [Vávra 2013]. Podobné poznatky - ovšem se zvláštním ohledem na systém formálního vzdělávání - přináší Denisa Labischová a její tým [Gracová - Labischová 2012; Labischová 2012]. Oba výzkumy potvrzují dominantní roli audiovizuálních médií (televizní vysílání, dokumentární filmy, historické hrané filmy) jako hlavního zdroje informací o minulosti pro své respondenty.

Je však nutné poznamenat, že výše uvedené výzkumy často implicitně pracují s jednotlivými informačními zdroji jako se vzájemně se vylučujícími kategoriemi (a to i v případě, kdy umožňují respondentům zaznamenat informačních zdrojů více) - předpokládají, že respondenti se např́íklad dozvídají o minulosti bud’ z dokumentárních filmů, nebo ze školního vyučování. Gracová a Labischová však poukazují na poměrně rozšířenou praxi, kdy jsou dokumentární filmy využívány jako součást školní výuky [Gracová - Labischová 2012: 533]. ${ }^{8}$ I když se tedy výše uvedené výzkumy zaměřují na četnosti užívání jednotlivých informačních zdrojů, nezaměřují se na to, jakým způsobem jsou tyto informační zdroje využívány, jaké mají vzájemné návaznosti, nebo na to, které informační zdroje zprostředkovávají který typ významů. Média (a další informační zdroje) jsou v tomto pojetí atomizovány a homogenizovány podobným způsobem, jako bylo počátkem dvacátého století nahlíženo jejich publikum.

Celkově vzato můžeme ve vztahu k dosavadnímu studiu kolektivní paměti v ČR hovořit o rozšířeném předpokladu přítomnosti nadindividuálních významů, jež regulují individuální jednání. Tyto předpoklady implicitně obsahují tezi, podle které aktéři (přesněji jejich mysli) mají plošný př́stup ke kulturním významům, kdy je působení informačních zdrojů (pokud je zohledňováno) předpokládáno jako jednoduché a př́mé. Tyto významy jsou pak jako neviditelné síly př́tomny v každé situaci a stávají se zdrojem explanace lidského jednání. ${ }^{9}$ Tento důsledek se potvrdí, přejdeme-li od reflexe východisek zkoumání kolektivní paměti k reflexi vysvětlování empirických jevů na základě takto identifikova-

\footnotetext{
7 V podobném ohledu si Melinda Milligan [2007] ve své studii o americkém hnutí ochrany památek všímá, že literatura věnující se kolektivní paměti se orientuje především na jevy kulturního rázu. Současně ale dodává, že interakcionistická perspektiva, kterou zaujímá, musí zohledňovat oba způsoby, kterými jsou budovy konstruovány - sociální i fyzikální. Jedině tak je podle této autorky možné načrtávat vztahy mezi sdílenými představami a lidmi vytvořeným prostředím [Milligan 2007: 109]. Tato autorka tak rozšiřuje interakcionistickou perspektivu ve směru, který - jak uvidíme níže - není některým klasickým autorům této sociologické tradice cizí.

8 Tyto autorky se ve své práci zaměřují na zkoumání vztahu školního vyučování a dalších informačních zdrojů, už se ale nevěnují dalším vztahům mezi informačními zdroji.

9 Například v teoreticky zaměřené studii Bernharda Giesena vystupuje pamět jako entita, která může ignorovat nebo vynechávat a do níž sociální skupiny ukládají své vzpomínky [Giesen 2007: 71]. Takový způsob vysvětlování ilustruje postřeh Jeffreyho Olicka, podle kterého sociologie při studiu kolektivní paměti často podléhá „pokušení“ vyobrazovat ji jako autonomní monolitickou entitu [Olick 2007: 51].
} 
ných východisek. Za tímto účelem budu pokračovat v interpretaci Oláhovy výše uvedené studie.

Po rozsáhlém a propracovaném popisu událostí doplněných o úryvky z rozhovorů dospívá Oláh k závěrům, jež korespondují s jeho počátečními východisky. Nejrazantněji formulovaný bod závěru reprezentuje pravděpodobně věta „pamět tedy řídí jednání lidí v prostoru pomocí významů“ [Oláh 2013: 746]. Podrobnější vyjádření tohoto bodu ale můžeme najít na následujících řádcích:

Významy, které jsou skryté, se při významných a výjimečných událostech, jakými byly protesty v roce 2006, vynořují na povrch a ovlivňují jednání lidí. [...] Role mimořádných událostí je signifikantní, protože odkazují na autonomii kultury, která dokáže motivovat a řídit jednání jedinců skrze významy. Určití jedinci útočili na památník v Budapešti kvůli významům, které se ten večer vynořily a oživily. Samozřejmě to umožnily i okolnosti, rozhořčení davu kvůli lži premiéra, útoky na památník v minulosti a nepřipravená policie [Debreczeni 2012], která nedokázala dostat situaci pod kontrolu [Oláh 2013: 747].

Z tohoto úryvku je zřejmé, že kulturní významy získávají svůj privilegovaný status při vysvětlování tím, že jsou nahlíženy jako prríčina zkoumaného jednání. Tyto významy jsou skryté, nejsou přímo pozorovatelné, ale to neubírá na jejich důležitosti - pokud jednání přímo neřídí, tak ho alespoň ovlivňují. V poslední větě úryvku sice Oláh zmiňuje i ostatní aspekty situace, které zasahovaly do výsledné události, ale je zřejmé, že primární role $\mathrm{v}$ prríčinnosti (a tedy i ve vysvětlení) je přisuzována významům náležejícím do autonomní sféry kultury.

Tuto formu explanace kritizuje $\mathrm{z}$ dnes již poměrně známé pozice Bruno Latour. Podle tohoto autora mají taková vysvětlení paradoxní povahu, protože vyžadují příliš časté postulování sil, které ačkoliv jsou považovány za příčinu pozorovaných jevů, zůstávají stále neviditelné [Latour 2005: 102]. Důsledkem takových explanačních strategií pak podle Latoura je, že pozorované fenomény velice rychle zmizí pod nálepkou některé ze sil užívaných pro vysvětlování [Latour 2000: 6; Latour 2003a: 3; Latour 2003b: 138]. Latour však samožrejmě není prvním pozorovatelem moderní vědy, který si této tendence všiml. V podobném duchu již v roce 1972 píše Gregory Bateson o „explanačních principech“ (explanatory principles). Podle tohoto autora představují explanační principy (poukazuje v tomto ohledu např́iklad na pojmy „instinkt“ nebo „gravitační síla“) konvenci vědců v tom, že snaha o vysvětlování jevů končí právě tímto bodem [Bateson 1972: 43]. Podíváme-li se na Latourovu kritiku strategií vysvětlování prizmatem konceptu explanačních principů, ztratí tato kritika něco ze své radikality; zároveň nám to ale umožní tuto kritiku produktivně využít. Ukáže se totiž, že cílem není explanační principy přestat používat. Jde spíše o to, neuchylovat se k explanačním principům př́liš̌ brzy a zužovat tak oblast zkoumatelného.

Shrnutí některých implikací Latourovy teorie pro studium kolektivní paměti můžeme najít ve studii Matthew Howarda [2014]. Ten už na začátku své argumentace poukazuje na to, že vyhneme-li se tradiční dichotomii aktéra a struktury, bude kauzalita klasických sociologických vysvětlení problematizována. Tuto problematičnost lze v duchu Latourovy teorie vyřešit tím, že se východiska soustřed’ující se kolem vlivu struktur na jednání nahradí východisky zaměřujícími se na jednání pomocí mobilizace sítě vztahů [Howard 2014, nestránkováno]. V tomto ohledu je však nutné poznamenat, že takový přístup nelze 
redukovat na přijímání teze, že „věci jednají“. Základní východisko tohoto přístupu spočívá v tom, že každého aktéra (at̉ už se jedná o člověka, nebo věc) je možné analyticky rozložit na sít vztahů - jež zahrnuje lidi i věci - a až tato sít vztahů umožňuje aktérům jednat. Věci samotné nejednají, stejně tak jako nejednají lidé bez pomoci věcí. K této „rozložitelnosti“ aktérů na sítě poukazuje už samotný název Actor-Network Theory.

Při zvažování těchto východisek pro studium kolektivní paměti můžeme poukázat na zcitlivující otázky navrhované Garym Finem a Aaronem Beimem [2007], které nám umožní posoudit současný stav badatelského pole a př́padný přínos nových východisek. Jimi formulované otázky jsou následující: „Měli bychom konceptualizovat kolektivní pamět jako proces, nebo jako jeho výsledek“ [Fine - Beim 2007: 2]? „Co se skrývá za působením kolektivní paměti: její inherentní charakteristiky, nebo zpo̊soby jejího šíření a přijímání [Fine - Beim 2007: 3]? „Jak se kolektivní pamět šírí a jak se projevuje - skrze média, nebo prostřednictvím osobního kontaktu“ [Fine - Beim 2007: 4]? Vezmeme-li v úvahu výše uvedenou argumentaci, můžeme dojít k závěru, že současné zkoumání kolektivní paměti konceptualizuje tento jev především jako určitý stabilní produkt sociálních procesů (významovou strukturu), přičemž se zaměřuje na jeho inherentní charakteristiky (obsahy významů). V tomto smyslu pokrývá současné bádání pouze část spektra načrtnutého Finem a Beimem. Navrhovaná východiska by pak mohla pomoci rozšírit záběr badatelského pole tak, aby zahrnovalo i proces šíření kolektivní paměti a zaměřovalo se na role různých zprostředkovatelů $\mathrm{v}$ tomto procesu.

Některé empirické studie také naznačují, jak horizont badatelského pole rozšírit. Například Jindra Tichá [2010] se v jedné ze svých studií zaměřuje na roli rodinné fotografie při vytváření a udržování skupinové paměti. Tichá sice v konečném důsledku sahá po klasické strategii vysvětlení pomocí sociálních rámců, ale ty už musí být v textu vyvažovány oproti objektům, jež fungují podle „logiky fotografického média“ [Tichá 2010: 98]. Objekt už zde tedy nefiguruje pouze jako tvárná projekce významu, ale jako věc operující podle vlastní logiky. ${ }^{10}$

Další studii ukazující tímto směrem napsali Martin Hájek a Marie Dlouhá [2011]. Tato studie je př́nosná tím, že nepracuje s představou paměti jako nějakého místa, kam se ukládají významy a vzpomínky, ale považují ji za kompetenci k rozpoznávání a nakládání s dokumenty paměti [Hájek - Dlouhá 2011: 34]. Pamět zde nepatří do skryté autonomní sféry, ale je pozorovatelná jako interakce mezi aktéry a hmatatelnými objekty (v tomto př́padě dokumenty), jde o „specifickou schopnost jednat“ [Hájek - Dlouhá 2011: 34]. V daném výzkumu šlo především o zjištování, jak se aktéři budou schopni vypořádat s úryvky textů, jež byly vyňaty z vyprávění pamětníků předlistopadového režimu. Hájek s Dlouhou tak sahají po přístupu, kterému říkají „etnometodologie čtení“ [Hájek - Dlouhá 2011: 49].

Odkaz k Haroldu Garfinkelovi napovídá mnohé. Tohoto autora totiž označuje Latour za svého předchůdce, s nímž sdílí přesvědčení, že sociologie by měla být vědou o tom, jak

10 Pokud bychom se v zahraniční literatuře ohlíželi po aplikaci podobného přístupu do oblasti zkoumání kolektivní paměti, narazíme na práci Jamese Wertsche [1991, 2002], který považuje vzpomínání za zprostředkované jednání (mediated action). Podle Wertsche aktéři při svém jednání používají „kulturní nástroje“, jako jsou např́íklad počítače, mapy nebo narativy. Jednání je pak charakteristické určitou tenzí, která vyvstává mezi aktivními aktéry na jedné straně a nástroji na straně druhé. Je tomu tak proto, že každý nástroj se vyznačuje určitými omezeními (constraints) a možnostmi (affordances), které se projevují v možných nebo ustálených způsobech jeho používání [Wertsch 2002: 11-13]. 
společnost drží pohromadě [Latour 2005: 13]. Tím má ovšem na mysli orientaci na vznik sociálního řádu v konkrétních situacích a ne explanaci jevů pomocí konceptů, jež mají zachycovat již existující sociální řád. Není pak divu, že Hájek s Dlouhou, zařazujíce Garfinkela k základům svého přístupu, nevysvětlují své zjištění (že reakce čtenářů byly překvapivě podobné napříc generacemi) pomocí autonomních významů nebo rámců, ale poukazují na určitou vlastnost („interpretační otevřenost“) dokumentů předkládaných respondentům a odkazují k místu, kde je podle nich pamět v moderních společnostech produkována, k masovým médiím [Hájek - Dlouhá 2011: 50-51].

Pokud se na tyto závěry podíváme prizmatem Actor-Network Theory, zjistíme, že tvrzení o interpretační otevřenosti můžeme reformulovat jako uvědomění si toho, že fragmenty textů předkládané respondentům nehrají jednoduchou roli prostředníků (intermediaries), ale že představují spiše špatně předvídatelné zprostředkovatele (mediators). ${ }^{11}$ Poukazem $\mathrm{k}$ masovým médiím pak tito autoři předznamenávají první z kroků latourovské analýzy lokalizaci globálního (localizing the global) [Latour 2005: 173]. Latour se totiž brání klasickému rozlišování mezi mikro- a makro- úrovněmi a namísto něj uplatňuje rozlišování lokalit s malým a velkým dosahem [Latour 2005: 176]. V této perspektivě by tak konkrétní místa masových médií, jako jsou studia, střižny, tiskárny, kanceláře a podobně, představovala právě lokality s velkým dosahem, kde je produkováno mimo jiné vědění orientované na minulost. Výzkumný program, který by se orientoval na tato „místa paměti“ však u nás zatím nebyl rozvinut. ${ }^{12}$

Zde se ovšem není nutné omezovat na tradiční masová média, jako je televize nebo tisk. Jde o zahrnutí lokací, kde dochází k produkci vědění o minulosti, od muzeí či archivů $\mathrm{k}$ Wikipedii, fórům nebo blogům. Tato místa můžeme podle Michaela Guggenheima [2009: 44-45] elementárně klasifikovat podle způsobu kontroly objektů, tedy podle toho, jestli jsou objekty izolovány od svého prostředí (muzejní exponáty, památníky apod.), nebo jestli jsou objekty standardizovány a šířeny (filmy, encyklopedická hesla apod.). Podle Tomáše Dvořáka [2014: 175] se v poslední době také vynořuje problém změny archivální logiky, protože oproti klasickým archivům, jež jsou uzpůsobeny pro stabilizaci a uchování, jsou digitální média orientována na permanentní přenos. Tento problém nabývá na významu, uvážíme-li, že podle některých zjištění se internet stal druhým nejvýznamnějším zdrojem informací o historii [Šubrt - Vinopal 2010: 13].

Celkově vzato by prŕnosem takového výzkumného zaměření byla vy̌̌ší citlivost $\mathrm{k}$ různým druhům entit, které se podílejí na vzniku situací a které také často pocházejí ze situací jiných a odkazují tak $\mathrm{k}$ dalším lokacím a temporalitám. Zohlednění toho všeho by nám

${ }^{11}$ Ve slovníku Actor-Network Theory představují prostředníci (intermediaries) entity, jež přenášejí význam, nebo vliv (force) bez transformace. To znamená, že jejich působení je obecně (na úrovni typu objektu) předvídatelné z působení jiných entit na ně. U zprostředkovatelů (mediators) naopak k transformaci dochází, a to způsoby, které nemusí být předvídatelné, pokud nejsou uvážena specifika konkrétního př́padu [Latour 2005: 39].

${ }^{12} \mathrm{~V}$ tomto ohledu je možné navázat např́klad na popis procesu vzniku kolektivní paměti Miroslava Hrocha [2014]. Tento proces se podle Hrocha dá rozdělit do pěti fází, přičemž v každé z nich dochází k selekci informací: a) informace jsou dochovány prostřednictvím pramenů, b) informace jsou zpracovány historiky, c) vzniká povědomí lidí o historii založené na šíření vědeckého poznání nebo na jiných formách komunikace, jako např́klad vyprávění, d) informace jsou zprostř̌edkovány školou, žurnalistikou, popularizací vědy atd., e) informace jsou označeny jako relevantní pro současné potřeby sociálních aktérů [Hroch 2014: 52]. Je zřejmé, že $\mathrm{v}$ takto popsaném procesu vzniku kolektivní paměti hraje důležitou roli mnohem širší množina míst a artefaktů, než je při studiu kolektivní paměti běžnou praxí zohledňovat. 
mohlo poskytnout úplnější obraz zkoumaného jevu, ještě než se jeho vysvětlování pokusíme uzavřít odkazem k explanačním principům ve formě významových struktur. Jde tedy především o to, neselektovat v rámci studia kolektivní paměti materiální objekty podle toho, jestli jsou uchopitelné jako jednorozměrné kotvy daného významu v prostoru a čase, ale zahrnovat i takové, jejichž význam je vícerozměrný, př́ípadně takové, které nám umožní vysvětlit šíření sdílených významů mezi aktéry. Na otázku šíření kulturních reprezentací se zaměřují přístupy, jimž se věnuji v následující části textu. Tam se budu snažit ukázat, že není nutné přijmout redukcionismus kognitivních neurověd, abychom se otázkou šíření sémantických obsahů mohli zabývat, a že pro tyto účely můžeme využít existujících sociálněvědních metod.

\section{Kognitivní přístupy ve zkoumání kolektivní paměti}

V této části textu se dostáváme do oblasti spadající pod kulturu nazvanou Olickem [1999] „shromážděná pamět“. Cílem tohoto textu ale není věnovat se celému spektru přístupů spadajících do této oblasti, nýbrž určitému typu př́istupů, které přijímají za svůj předpoklad, že pamětí může disponovat pouze jednotlivec. Zároveň se na tento jev na individuální úrovni dívají jako na kognitivní proces, což do značné míry určuje další teoretická a metodologická východiska těchto př́istupů. V následujících odstavcích se tedy budu věnovat kognitivistickým prrístupům ke zkoumání kolektivní paměti.

Tyto přístupy jsou v obecné rovině charakteristické tím, že zdůrazňují roli tělesných (neurofyziologických) procesů při zkoumání kulturních jevů. Na rozdíl od přístupů předpokládajících kulturní autonomii, které se soustředují na vlastnosti významových kategorií jako takových, se tyto přístupy naopak zaměřují na to, jak vlastnosti lidského těla ovlivňují tvorbu a šíření těchto významů. V tomto ohledu může být prríkladným přístup George Lakoffa, který tvrdí, že vlastnosti pojmových kategorií jsou spoluurčovány právě tělesnou zkušeností lidí, kteří kategorizace provádějí [Lakoff 2006: 357].

Základy tohoto přístupu pokládal například už v roce 1996 Dan Sperber [1996]. Podle tohoto autora spočívá zkoumání kulturních reprezentací v hledání vysvětlení jejich rozšiřování. Sperber tak navrhuje rozvíjet výzkumný program „epidemiologie reprezentací" [Sperber 1996: 82]. Ten má být založen na evolučním principu přirozené selekce, jenž určuje, které reprezentace budou v prostředí tvořeném lidskou kognicí přežívat, případně se rozšiřovat [Sperber 1996: 105]. Zkoumání kulturních reprezentací pak v tomto př́ístupu předpokládá neurofyziologický výzkum lidské kognice, aby bylo možné určit determinanty prostředí, v němž by se reprezentace měly „množit“. Podobný přístup spočívající v epidemiologii kulturních reprezentací navrhuje specificky pro studium kolektivní paměti aktuálněji např́íklad Pascal Boyer [2009]. Tento autor se již ve své dřívější práci pokusil vysvětlit šíření náboženských představ tak, že poukazoval na některé jejich charakteristiky, které jsou podle něj v souladu s dispozicemi lidské kognice [Boyer 2001: 326-27]. Ačkoliv $\mathrm{v}$ tomto př́stupu můžeme najít analýzy charakteristik kulturních představ jako takových, tyto jsou vždy vztahovány ke zjištěným univerzálním vlastnostem lidské kognice a až na základě vzájemného srovnání těchto dvou typů charakteristik může být rozšířenost určitých kulturních reprezentací vysvětlena.

Základní teze těchto př́istupů navrhuje v českém prostředí aplikovat do oblasti studia kolektivní paměti Dušan Lužný [2014]. Tento autor navrhuje studium kulturní paměti 
doplnit o orientaci na kognitivní procesy ve výše uvedeném smyslu. V tomto př́padě se jedná o doplnění převládající orientace na kulturní významy o orientaci na materiálno, tentokrát však se zaměřením na lidské tělo. Studium kolektivní paměti by podle Lužného mělo najít vyváženou pozici mezi sociálním konstruktivismem a realismem kognitivních věd [Lužný 2014: 15]. V následujících odstavcích budu pracovat s Lužného studií Kulturní pamět jako koncept sociálních věd jako s ilustrativním textem, který se snaží aplikovat kognitivní př́stupy do oblasti studia kolektivní paměti.

Podle Lužného se kognitivní přístupy vyznačují tím, že hledají „invarianty či determinanty, které nejsou závislé na určitém diskurzivním prostředí“ [Lužný 2014: 13]. Kognitivní determinanty tedy nejsou závislé na diskurzivním prostředí, z čehož se odvozuje jejich neměnnost např́ič časem a populacemi (jsou to invarianty) a prvotní pozice při vysvětlování (jsou to determinanty - nezávislé proměnné). ${ }^{13}$ Tyto invarianty by měly vysvětlit, proč se některé prvky kultury šíŕi lépe než jiné a zdají se proto být udržovány v paměti na rozdíl od těch, jež nejsou. $\mathrm{V}$ tomto ohledu jde tedy o tezi antinomickou k té o autonomii kultury. V této perspektivě není kultura pojímána durkheimovsky, jako entita sui generis, ale jevy náležející do její oblasti jsou (alespoň do určité míry) vysvětlitelné pomocí odkazu k univerzálním determinantám nacházejícím se v mozku člověka [Lužný 2014: 13].

Místo, kde by se konstruktivismus mohl protínat s kognitivistickým přístupem, nachází Lužný v konceptu vtělené kognice (embodied cognition), konkrétně ve zkušenostním realismu George Lakoffa [2006]. Význam konceptu vtělené kognice se podle Lužného nachází v tezi, podle níž kognice existuje vždy v kontextu určitého prostředí a času, a je tedy nutné zkoumat ji ve vztahu k tomuto kontextu [Lužný 2014: 16]. Pokud však toto prostředí budeme hledat v tezích, jež Lužný odvozuje z Lakoffova zkušenostního realismu, zjistíme, že toto prostředí je tvořeno lidským tělem na straně jedné a systémem kulturních významů na straně druhé. Opět se zde proto objevuje předpoklad, podle něhož je lidská mysl plošně napojena na kulturní významy.

Vezmeme-li v úvahu, že kulturní významy (potažmo jejich šíření) jsou to, co má být vys větleno, nacházíme zde silný důraz na zkoumání kognitivních procesů lokalizovaných v lidském těle jakožto potenciálních zdrojů kauzálního vysvětlení. Otázkou však zůstává, zda je možné sledovat kauzální vztah napříč úrovněmi tradičně definovanými jednotlivými obory? A za předpokladu, že to možné je, zda při překonávání hranice mezi úrovněmi (a obory) nedojde ke ztrátě empirické návaznosti jednotlivých zjištění a nedojde tak pouze $\mathrm{k}$ přidání nové skupiny explanačních principů $\mathrm{k}$ té již existující? Zjednodušeně řečeno, není jasné, jestli výsledkem posunu ke kognitivistickému př́istupu navrhovanému Lužným nebude to, že vysvětlení pomocí významů a rámců nahradíme či doplníme o vysvětlení pomocí invariant, jakou je například pamět, která je „imaginativni““ a „celostni““ [Lužný 2014: 16].

Celkově vzato, přístup navrhovaný Lužným je fixován na lidské tělo (případně jeho část - mozek) a do jeho prostředí přiznává pouze to, co má být pomocí jeho zkoumání vysvětleno - kulturní významy. Jde tak opět o orientaci na specifickou výseč materiality (podobně jako tomu bylo u orientace klasických př́istupů zkoumání paměti na materiální

13 Na problematičnost takového př́stupu však narážel už Clifford Geertz, když poukazoval na to, že kognitivní struktury mozku se vyvíjí v návaznosti na dlouhodobě přetrvávající sociální a kulturní prostředí lidského organismu [Geertz 1973: 67]. Kritika vedená z této pozice by problematizovala předpoklad o neměnnosti a nezávislosti daného typu proměnných. 
symboly, jakými jsou památníky). Vedle konceptu vtělené kognice se tak nabízí postavit zdánlivě podobný koncept distribuované kognice (distributed cognition), jenž je ve své současné podobě rozvíjen minimálně od poloviny devadesátých let.

Jedním z ústředních autorů tohoto přístupu je Edwin Hutchins [1995], ${ }^{14}$ který ve své nejznámější práci založené na etnografickém výzkumu navigačního týmu námořní lodi popsal proces, při kterém malá skupina aktérů určuje polohu lodi. Hutchins zde zdůrazňuje význam nástrojů pro práci skupiny a popisuje je jako nepostradatelnou součást kognitivního systému - používá pro jejich označování doslova výraz „materiální prostředky myšlení (material means of thought). Podle tohoto autora se pak proměny povahy a konfigurace těchto prostředků myšlení promítají do měnících se reprezentací kognitivních problémů [Hutchins 1995: 367]. V návaznosti na svou analýzu Hutchins tvrdí, že myšlení, jak je tradičně uváděno, sice sestává z manipulace se symboly, ovšem tato manipulace není výhradně abstraktní. Manipulace se symboly je zprostředkovávána kulturními a materiálními objekty, které jsou pro kognitivní procesy konstitutivní [Hutchins 1995: 363]. Autoři pracující s konceptem distribuované kognice ${ }^{15}$ tak prosazují tezi, podle níž není lidská kognice jevem lokalizovatelným výhradně v lidském mozku, ale podle níž je naopak tvořena systémem objektů distribuovaných v prostoru, přičemž tento systém není omezován hranicemi lidského těla. Andy Clark a David Chalmers tuto tezi shrnují následujícím způsobem:

Pokud při řešení nějakého problému vystupuje část vněǰ̌ího světa jako proces, jenž bychom bez váhání označili jako kognitivní, pokud by se odehrával v hlavě, pak tvrdíme, že tato část světa je součástí daného kognitivního procesu [Clark-Chalmers 1998: 8].

Podle Ronalda Giera jsou kognitivní systémy definovány tím, že produkují vědění [Giere 2002: 642]. Z toho sice vyplývá jasná návaznost na lidské jednání, ale taková definice zároveň nevylučuje zahrnutí objektů externích lidskému tělu. Pro další vymezení kognitivních systémů ve výše nastíněném smyslu je možné se vrátit ke Clarkovi a Chalmersovi, kteří rozlišují mezi pragmatickým jednáním (proměna vnějšího světa, jejímž účelem je tato proměna samotná) a epistemickým jednáním (proměna vnějšího světa, jejímž účelem je podpořit poznávací procesy) [Clark-Chalmers 1998: 8]. Kognitivní systémy pak můžeme nahlížet jako systémy, jejichž těžištěm je právě epistemické jednání.

Objekty, které jsou mobilizovány epistemickým jednáním, pak Clark označuje za „wideware“ a definuje je jako objekty, které „působí tak, že zpracovávají, uchovávají nebo

14 Hutchinsova práce je součástí širší linie myšlení, kterou reprezentují autoři jako Jean Lave [1988] nebo Lucy Suchman [1987, 2007] a která nachází svou aplikaci v oblastech, jako je studium interakce člověk-počítač (human-computer interaction) [Wright - Fields - Harrison 2000], náboženství [Lawson 1999; Reimer 2005], morálky [Magnani - Bardone 2008], př́ípadně práce [Rogers - Ellis 1994]. Ústřední teze teorie distribuované kognice také připomíná obraz „kyborgư“, jež ve své klasické práci popsala Donna Haraway: „Proč by měla naše těla končit kůží, nebo přinejlepším zahrnovat jiné bytosti ohraničené kůží? Už od 17. století mohly být stroje animovány - dostávaly přízračné duše, aby mohly mluvit nebo se pohybovat, případně aby dohlížely na svi̊j spořádaný vývoj a mentální schopnosti. Na druhé straně mohly být organismy mechanizovány - redukovány na těla nahlížená jako zdroje pro mysl. Tyto vztahy mezi organizmy a stroji jsou zastaralé a zbytečné. V naší imaginaci a jiných praxích mohou být stroje protetickými pomůckami, intimními součástkami, prátelským Já“ [Haraway 2006: 144].

15 Mezi další autory, kteří se věnují teorii distribuované kognice, patří především Andy Clark [1998, 2006; Clark Chalmers 1998] nebo Ronald Giere [Giere 2002; Giere - Moffatt 2003]. Z českých autorů se pak můžeme s touto teorií setkat v práci Jana Krátkého [2013]. 
proměňují vědění a informace, které organismus používá k dosažení svých cílư “ [Clark 1998: 269]. Sociologická relevance takového přístupu pak spočívá v tom, že - jak Ronald Giere a Barton Moffat zdůrazňují - konkrétní formy distribuce aktérů a objektů souvisí s existujícími sociálními strukturami [Giere - Moffatt 2003]. ${ }^{16}$ Hutchins v tomto ohledu sám podobným zpo̊sobem odkazuje na kulturní kontext jednání, když tvrdí, že konfigurace kognitivních systémů jsou formovány v rámci kulturou informované praxe [Hutchins 2011: 445]. Tímto důrazem na socializaci a enkulturaci distribuované kognice se zmínění autoři vyhýbají redukcionismu, který by byl implikován odkazem k fyziologickým procesům souvisejícím s kognicí.

Z navrhovaného užívání kultury při vysvětlování konkrétních podob konfigurace systémů distribuované kognice by se mohlo zdát, že jsme opsali kruh a vrátili jsme se do výchozího bodu, kdy je kultura nahlížena jako autonomní sféra a formující síla. Tento přístup se však od toho původního liší v tom, že danou kulturní praxi ukotvuje do podoby manipulace s objekty, jež je možné klasifikovat jako wideware. Jinými slovy řečeno, tento př́stup bere v úvahu materiální mediaci kulturních pravidel v situaci jednání a vyhýbá se tak spojování mysli a kultury způsobem, který předpokládá, že mysl má přímý přístup ke kultuře jako celku a že kultura může působit na mysl neomezeným způsobem. Navíc tím, že jsou kulturní vlivy lokalizovány v různých objektech, nenabývají při vysvětlování automaticky nadindividuální povahy, nýbrž zůstávají stejnými součástmi situace jako individuální aktéři.

Taková lokalizace globálních jevů odpovídá, jak jsme viděli, Latourovu přístupu a je slučitelná s jeho metaforou plochých sítí. Tato kompatibilita však není náhodná. Latour přišel s podobnou tezí jako Hutchins už ve druhé polovině osmdesátých let [Latour 1986]. ${ }^{17}$ Podobně jako se Hutchins zabýval transformací pozorování orientačních bodů v určení polohy lodi na mapě, Latour se věnoval transformaci přírodních jevů ve vědecké texty. Oba autoři zdůrazňují nezastupitelné místo nástrojů a dalších objektů pro takové transformace. ${ }^{18}$ Latour ve své teorii však navíc popisuje proces mobilizace jako praxi prosazování a přesvědčování, rozpracovává koncept černých skříněk, což mu umožňuje rozlišovat mezi prostředníky (intermediaries) a zprostředkovateli (mediators), a představuje specifický přístup k popisu a vysvětlování jevů, jenž byl nastíněn výše. Specifikem tohoto přístupu opět je, že ačkoliv se zaměřuje na kognitivní aspekty sociálních jevů, neuchyluje se přitom k redukcionismu, jenž by vyplýval ze studia lidské fyziologie, a je možné jej uplatňovat v empirickém výzkumu s využitím již existujících společenskovědních metod (převážně etnografie).

16 Takové propojení wideware a sociologické relevance odpovídá např́íklad argumentaci, kterou rozvíjí Lynn Spillman a Brian Conway [2007]. Ti využívají koncept vtělené paměti (embodied memory), avšak poznamenávají, že aby se jednalo o více než jen osobní problémy, musí být obsahy paměti kolektivně označeny (inscription) a musí proběhnout určitá forma mobilizace aktérů a dalších entit [Spillman - Conway 2007: 95].

17 Pokud bychom však chtěli sledovat historii tezí typických pro teorii distribuované kognice, došli bychom minimálně k dílu G. H. Meada, které - jak ukazuje Jiří Šubrt [2015] ve své nedávné recenzní eseji - předznamenává mnohé z myšlenek, které se v nich objevují. Podle Šubrta však byl tento rozměr Meadova díla překryt pozdějším spojením symbolického interakcionismu a interpretativní sociologie [Šubrt 2015: 707]. V tomto světle můžeme chápat přístupy teorie distribuované kognice a Actor-Network Theory jako jakýsi návrat ke kořenům interakcionismu.

18 Latour [2005: 60] považuje Hutchinsův př́stup v mnohém za kompatibilní s tím svým. Podrobné srovnání a jeho kontextualizace do diskuze o tom, nakolik může být vědomí distribuované, by však pravděpodobně vydalo na samostatnou studii. 
V tomto ohledu však není nutné vydávat se přímo cestou čisté Actor-Network Theory, případně omezovat spektrum využitelných metod pouze na etnografii. Níže se pokusím ukázat již existující teoreticko-metodologický přístup, který si klade za cíl integraci badatelských zaměření na kulturní významy na straně jedné a materiální objekty na straně druhé, přičemž obojí nahlíží jako elementy zkoumaných situací.

\section{Situační analýza a dosavadní explanační principy}

Adele Clarke rozvíjí situační analýzu jako odnož zakotvené teorie minimálně už od přelomu století [Clarke 2003, 2005]. Se zakotvenou teorií má tento př́ístup společné základní procedury kvalitativní analýzy, jako je kódování, tvorba poznámek nebo teoretické vzorkování [Charmaz 2006; Corbin - Strauss 2008]. Zachován zůstává také důraz na konstantní komparaci při analýze dat [Clarke - Friese 2014: 72]. Klíčový bod, v němž se situační analýza s klasickou zakotvenou teorií rozcházejí, se nachází ve způsobu uchopení sociálních podmínek jednání. Zatímco zakotvená teorie pracuje s podmínkami jako s kontextem, který se nachází vně situace jednání, ale nějakým zpơsobem ji ovlivňuje, situační analýza se drží teze, podle níž jsou všechny podmínky jednání přítomny v situaci jako její elementy. Kontext jako by pro situační analýzu neexistoval [Clarke - Friese 2014: 68], veškeré podmínky jednání musí být zastoupeny elementy v situaci, at’ už je jejich povaha jakákoli [Clarke 2015: 98]. S ohledem na výše načrtnutou diskuzi pak můžeme nahrazení obecnějších kontextuálních podmínek konceptem situace vnímat jako pojistku proti reifikaci nadindividuálních významových struktur při zkoumání a vysvětlování jevů souvisejících s kolektivní pamětí. Kolektivní pamět v této perspektivě představuje situované praxe vzpomínání a předávání vzpomínek. ${ }^{19}$ Takové pojetí kolektivní paměti se zdá být jednoznačnější a lépe vymezitelné vůči pojmu kultury [Kapusta 2013: 78].

Právě různorodost povahy elementů, kterou situační analýza předpokládá, je klíčovým bodem vzhledem k prredchozí argumentaci tohoto textu. Za prvé, situační analýza předpokládá, že elementy mohou být jak lidé (humans), tak ne-lidé (non-humans). V rámci druhé z těchto kategorií pak situační analýza rozlišuje mezi non-humans diskurzivní a materiální povahy. Situační analýza tak v sobě podle Clarke integruje vlivy jak Foucaultovy teorie diskurzu, tak Latourovy Actor-Network Theory [Clarke 2015: 90-92]. Je tedy uzpůsobená k zachycování významů, o nichž aktéři mluví nebo které jsou připisovány různým objektům (například památníkům), zároveň ale předpokládá působení různých materiálních objektů, které významy zprostředkovávají nebo umožňují či omezují jednání aktérů. Tyto typy elementů jsou do analýzy zahrnovány na základě jejich přítomnosti ve zkoumané situaci - jsou tedy pozorovatelné bud' prrímo, nebo o nich aktérí alespoň vypovídají a tím je v situaci zpřítomní. Tento přístup tedy nepředpokládá přímé pozorování situace jednání (jak to předpokládá například etnografie), ta může být rekonstruována na základě výpovědí informantů a tvoří tak spíše základní jednotku analýzy, ne pozorování.

Pro účely analýzy situace jsou zpravidla tvořeny situační mapy, které souhrnně vizualizují elementy zkoumané situace a směřují analýzu jednak k jejich kategorizaci [Clarke 2015: 102], jednak k popisování vzájemných vztahů mezi elementy [Clarke 2015: 107].

19 Toto vymezení také koresponduje s prací Jeffreyho Olicka [1999: 346], který považuje kolektivní pamět za zcitlivující koncept označující procesy, praxe a objekty, jež mají specificky mnemonický rozměr. 
Tato analytická strategie tvoří jeden ze tří typů analýzy v rámci celkového přístupu, který Adele Clarke rozvíjí. Analýza situace, jak je výše popsaný typ označován, je dále doplněna o analýzu sociálních arén - zaměřující se na organizace a další kolektivní aktéry, kteří rozvíjejí diskurzy nacházející se ve zkoumané situaci - a o analýzu pozic - zaměřující se na stanovování kritérií, jež odlišují pozice zaujímané v rámci diskurzivního prostoru [Clarke 2015: 99]. Oba následující typy analýz se však vztahují ke společnému základu v podobě analýzy situace zkoumaného jednání. Analýzu situace však doplňují tím, že se zaměřují na organizace rozvíjející a šírící relevantní diskurzy (což by ve slovníku Actor-Network Theory znamenalo zaměření na místa s velkým dosahem) a na exploraci logických možností vztahování se, které relevantní diskurzy nabízejí. Situační analýza jako celek tak věnuje dostatečnou pozornost významovým strukturám, ale neomezuje se jen na ně. Zaměřuje se na místa, kde jsou významy produkovány, a ukotvuje významy v situaci jejich využívání spolu s elementy materiální povahy, přičemž načrtává jejich vzájemné vztahy. V rámci studia kolektivní paměti pak takový prŕístup znamená soustředění pozornosti k situacím se specificky mnemonickým rozměrem a kladení otázek, jako například: Jaké objekty, média, praxe a významy tyto situace zahrnují? Kde mají používané diskurzy původ? Jak se diskurzy k aktérům dostávají a jak se k nim aktéři vztahují? Jak aktéři nakládají s objekty a médii a jak jim tyto umožňují jednat? Mají aktéři v tomto ohledu ustálené kompozice a praxe?

V českém prostředí se situační analýzou systematicky zabývá Jan Kalenda [2016a, $2016 b]$. Tento autor poukazuje na čtyři tradice tvořící myšlenkové zdroje situační analýzy - symbolický interakcionismus [Blumer 1986], Foucaultovu teorii diskurzu [Foucault 1977], Straussovu teorii sociálních světů [Strauss 1984] a Latourovu Actor-Network Theory [Latour 2005] - a konstatuje, že situační analýza se díky explicitnímu spoléhání na tato východiska vyhýbá některým bodům kritiky, jimž byla vystavena zakotvená teorie ve své klasické formě (šlo především o kritiku pozitivistických východisek zakotvené teorie) [Kalenda 2016a: 460]. V tomto ohledu tvoří situační analýza jakýsi integrovaný „balík“ explicitně formulovaných teoretických východisek a na ně navazujících metod [Clarke 2015: 87]. Kalenda aplikuje uvedený teoreticko-metodologický přístup především do studia v oblasti pedagogických věd [Kalenda 2016a]. Současně ale dokládá potenciál tohoto přístupu pro ustavování interdisciplinárních výzkumných vazeb [Kalenda 2016b]. Zdá se tak, že situační analýza by mohla být vhodným kandidátem pro rozšíření badatelského pole v oblasti studia kolektivní paměti, protože by měla být schopna úplněji pokrýt výše uvedené zcitlivující otázky, které si Gary Fine a Aaron Beim v roce 2007 kladli - analýzy situace, sociálních světů a pozic nám mohou poskytnout úplnější obraz toho, co se skrývá za působením kolektivní paměti nebo jak se kolektivní pamět šírí.

\section{Závěr}

Tento text se snaží argumentačně ukotvit několik postřehů, jejichž zohlednění by mělo vést k rozšíření výzkumného pole, na němž je založeno studium kolektivní paměti. První z bodů, který se text pokouší demonstrovat, je, že studie kolektivní paměti vydávané v Česku typicky předpokládají všudypř́ítomnost struktur kulturních významů, které následně užívají jako explanační principy a uzavírají tak proces vysvětlování dříve, než je možné zohlednit entity, jež mají jinou povahu. 
Přímé vysvětlování jednání pomocí významu je, jak jsme viděli, založeno na předpokladu, že mysl aktérů, jejichž jednání je vysvětlováno, má plošný a přímý přístup ke kultuře a jejím obsahům. Role prostředníků mezi aktéry a kulturou je přisuzována pouze objektům (například pomníkům), které představují zhmotnění významů a byly většinou za účelem symbolizace vytvořeny. V této roli však objekty vystupují pouze jako pasivní povrchy, sloužící výhradně projekci významů. V takové perspektivě by objekty nebyly schopny se „vzpírat“ libovůli aktérů a jimi konstruovaných významů.

Takový stav naznačuje potřebu zohlednění aktivní role, kterou materiální rovina může ve vztahu ke kolektivní paměti sehrávat - např́iklad při zprostředkovávání významů. Jednou $\mathrm{z}$ takových alternativ může být kognitivismus, jenž se v českém kontextu se studiem kolektivní paměti snaží propojit Lužný. Tento př́istup však vykazuje určitá omezení: za prvé předpokládá primát fyziologické složky jevu, čímž se přiklání k redukcionismu; za druhé je založený na poznatcích oboru, jenž se radikálně odlišuje od sociálních věd a jenž využívá naprosto odlišnou metodologii. Uplatnění tohoto přístupu v sociálněvědním studiu kolektivní paměti by tak pravděpodobně znamenalo spíše vybavení těchto oborů novou sadou konečných explanačních principů než rozšíření akčního pole výzkumu jako takového.

Z tohoto pohledu se zdá být plodnější alternativou přístup situační analýzy zohledňující klíčové premisy teorie distribuované kognice a Actor-Network Theory, jak byly nastíněny výše. Tento přístup se totiž projevuje v různých oblastech (sociálněvědní) badatelské činnosti rovnoměrně: rozšiřuje oblast empirických jevů, které mohou být brány v úvahu (a to se projevuje na modifikaci explanačních principů), přičemž ale umožňuje využívat existujících sociálněvědních metod. Studium kolektivní paměti odpovídající tomuto př́stupu se zatím v rámci českého badatelského prostředí projevovalo spíše náznaky a v některých případech nereflektovaně. Přitom by takový přístup mohl sloužit přinejmenším jako alternativa k hlavnímu proudu studia kolektivní paměti, jenž - jak se zdá tenduje ke kulturnímu determinismu.

\section{Literatura}

Bateson, Gregory [1972]. Steps to an Ecology of Mind: Collected Essays in Anthropology, Psychiatry, Evolution, and Epistemology. Chicago: University of Chicago Press.

Blumer, Herbert [1986]. Symbolic Interactionism: Perspective and Method. Englewood Cliffs: Prentice Hall.

Boyer, Pascal [2001]. Religion Explained: The Evolutionary Origins of Religious Thought. New York: Basic Books.

Boyer, Pascal [2009]. Cognitive Predispositions and Cultural Transmission. In. Boyer, Pascal - Wertsch, James (ed.). Memory in mind and culture. Cambridge: Cambridge University Press, s. 288-319.

Burzová, Petra L. - Dvořáková, Ilona - Hejnal, Ondřej - Růžička, Michal - Toušek, Laco [2013]. Pamět a prostor: Reprezentační strategie společenstva vzpomínání v postindustriálním městě. Sociální studia / Social Studies 10 (4): 107-26.

Charmaz, Kathy [2006]. Constructing Grounded Theory: A Practical Guide Through Qualitative Analysis. London: Sage Publications.

Clark, Andy [1998]. Where Brain, Body, and World Collide. Daedalus 127 (2): 257-80.

Clark, Andy [2006]. Material Symbols. Philosophical Psychology 19 (3): 291-307.

Clark, Andy - Chalmers, David [1998]. The Extended Mind. Analysis 58 (1): 7-19.

Clarke, Adele [2003]. Situational Analyses: Grounded Theory Mapping After the Postmodern Turn. Symbolic Interaction 26 (4): 553-76. 
Clarke, Adele [2005]. Situational Analysis: Grounded Theory After the Postmodern Turn. Thousand Oaks, CA: Sage.

Clarke, Adele [2015]. From Grounded Theory to Situational Analysis. What's New? Why? How? In. Clarke, Adele - Friese, Carrie - Washburn, Rachel (ed.). Situational analysis in practice: Mapping research with grounded theory. Walnut Creek, CA: Left Coast Press, s. 84-118.

Clarke, Adele - Friese, Carrie [2014]. Grounded Theorizing Using Situational Analysis. In. Clarke, Adele Charmaz, Kathy (ed.). Grounded theory and situational analysis. situational analysis: Essentials and exemplars, vol. IV. London: SAGE, s. 67-90.

Corbin, Juliet - Strauss, Anselm [2008]. Basics of Qualitative Research. Thousand Oaks, CA: Sage.

Durkheim, Émile [1969]. Pravidla sociologické metody. Praha: Vysoká škola politická ÚV KSČ.

Dvořák, Tomáš [2014]. Přepisování paměti. In. Maslowski, Nicolas - Šubrt, Jiří (ed.). Kolektivní pamět: K teoretickým otázkám. Praha: Karolinum, s. 170-76.

Fine, Gary Alan - Beim, Aaron [2007]. Introduction: Interactionist Approaches to Collective Memory. Symbolic interaction 30 (1): 1-5.

Foucault, Michel [1977]. Discipline and Punish: The Birth of the Prison. New York: Vintage.

Geertz, Clifford [1973]. The Interpretation of Cultures: Selected Essays. New York: Basic Books.

Giere, Ronald N. [2002]. Discussion Note: Distributed Cognition in Epistemic Cultures. Philosophy of Science 69 (4): 637-44.

Giere, Ronald N. - Moffatt, Barton [2003]. Distributed Cognition: Where the Cognitive and the Social Merge. Social Studies of Science 33 (2): 301-10.

Giesen, Bernhard [2007]. V různém čase, v různém rytmu a s rozdílnou pamětí. Sociální studia / Social Studies 4 (1): 67-78.

Gracová, Blažena - Labischová, Denisa [2012]. Současná teorie a praxe dějepisného vzdělávání na školách. Pedagogická orientace 22 (4): 516-43.

Guggenheim, Michael [2009]. Building Memory: Architecture, Networks and Users. Memory studies 2 (1): 39-53.

Halbwachs, Maurice [1992]. On Collective Memory. Chicago: University of Chicago Press.

Haraway, Donna [2006]. A Cyborg Manifesto: Science, Technology, and Socialist-Feminism in the Late 20th Century. In. Weiss, Joel - Nolan, Jason - Hunsinger, Jeremy - Trifonas, Peter (ed.). The international handbook of virtual learning environments. New York: Springer, s. 117-58.

Hájek, Martin - Dlouhá, Marie [2011]. Interpretační kooperace v biografických textech. Biograf 54: 57 odst.

Howard, Matthew [2014]. Lest We Forget (Matter): Post-Human Memory and Responsibility [online]. Dostupné z: <https://ecpr.eu/Events/PaperDetails.aspx?PaperID=22324\&EventID=14> [cit. 9. 1. 2017].

Hroch, Miroslav [2014]. Pamět a historické vědomí očima historika. In. Maslowski, Nicolas - Šubrt, Jiří (ed.). Kolektivní pamèt: K teoretickým otázkám. Praha: Karolinum, s. 46-65.

Hutchins, Edwin [1995]. Cognition in the Wild. Cambridge, MA: MIT Press.

Hutchins, Edwin [2011]. Enculturating the Supersized Mind. Philosophical Studies 152 (3): 437-46.

Kalenda, Jan [2016a]. Prozatím nevyužitá šance: situační analýza v pedagogickém výzkumu. Pedagogická orientace 26 (3): 457-81.

Kalenda, Jan. [2016b]. Situational Analysis as a Framework for Interdisciplinary Research in the Social Sciences. Human Affairs 26 (3): 340-55.

Kapusta, Jan [2013]. Vtělení paměti a minulosti do svatojakubské cesty a společensko-vědního diskurzu. Historická sociologie 5 (2): 75-94.

Krátký, Jan [2013]. Mezi lidmi a věcmi: Experimentální výzkum vlivu prostředí na prosociální jednání. Sociální studia / Social Studies 10 (2): 45-61.

Kunt, Gergely - Szeg, Dóri - Vajda, Júlia [2013]. Politická komunikace v př́ibězích zneuctěných památníků. Sociální studia / Social Studies 10 (4): 35-56.

Labischová, Denisa [2012]. Factors Shaping the Historical Consciousness of Pupils, Students and Teachers in Czech Schools. The New Educational Review 29 (3): 148-61.

Lakoff, George [2006]. Ženy, oheň a nebezpečné věci. Co kategorie vypovídají o naší mysli. Praha: Triáda.

Latour, Bruno [1986]. Visualization and Cognition. Knowledge and society 6 (1): 1-40. 
Latour, Bruno [2000]. When Things Strike Back: A Possible Contribution of „Science Studies“ to the Social Sciences. The British Journal of Sociology 51 (1): 107-23.

Latour, Bruno [2003a]. The Promises of Constructivism. In. Ihde, Don (ed.). Chasing Technoscience: Matrix for Materiality. Bloomington: Indiana University Press, s. 1-18.

Latour, Bruno [2003b]. We Have Never Been Modern. Cambridge, MA: Harvard University Press.

Latour, Bruno [2005]. Reassembling the Social: An Introduction to Actor-Network-Theory. New York: Oxford University Press.

Lave, Jean [1988]. Cognition in Practice: Mind, Mathematics and Culture in Everyday Life. Cambridge: Cambridge University Press.

Lawson, Matthew P. [1999]. The Holy Spirit as Conscience Collective. Sociology of Religion 60 (4): 341-61.

Lužný, Dušan [2014]. Kulturní pamět jako koncept sociálních věd. Studia philosophica 61 (2): 3-18.

Magnani, Lorenzo - Bardone, Emanuele [2008]. Distributed Morality: Externalizing Ethical Knowledge in Technological Artifacts. Foundations of Science 13 (1): 99-108.

Marková, Blanka - Šlach, Ondřej [2013]. Governance kulturou tažené urbánní regenerace: Př́padová studie Černá louka v Ostravě. Sociální studia / Social Studies 10 (4): 127-143.

Maslowski, Nicolas - Šubrt, Jiří [2014]. Kolektivní pamět: k teoretickým otázkám. Praha: Karolinum.

Maur, Eduard [2014]. Památná místa: Místa paměti ve vlastním (tj. topografickém) smyslu slova. In. Maslowski, Nicolas - Šubrt, Jiří (ed.). Kolektivní pamět: K teoretickým otázkám. Praha: Karolinum, s. 141-54.

Milligan, Melinda J. [2007]. Buildings as History: The Place of Collective Memory in the Study of Historic Preservation. Symbolic Interaction 30 (1): 105-23.

Oláh, Gábor [2013]. Kolektivní pamět', prostor a významy. Případ náměstí Svobody v Budapešti. Sociologický časopis / Czech Sociological Review 49 (05): 729-750.

Olick, Jeffrey K. [1999]. Collective Memory: The Two Cultures. Sociological Theory 17 (3): 333-348.

Olick, Jeffrey K. [2007]. Collective Memory and Nonpublic Opinion: A Historical Note on a Methodological Controversy About a Political Problem. Symbolic Interaction 30 (1): 41-55.

Parsons, Talcott [1971]. Společnosti: Vývojové a srovnávací hodnocení. Praha: Svoboda.

Reed, Isaac - Alexander, Jeffrey [2009]. Social Science as Reading and Performance a Cultural-Sociological Understanding of Epistemology. European Journal of Social Theory 12 (1): 21-41.

Reimer, Kevin [2005]. Fiat Lux: Religion as Distributed Cognition. Journal of Psychology \& Christianity 24 (2): 130-39.

Rogers, Yvonne - Ellis, Judi [1994]. Distributed Cognition: An Alternative Framework for Analysing and Explaining Collaborative Working. Journal of information technology 9 (1): 119-128.

Skovajsa, Marek [2014]. Struktury významu: Kultura a jednání v současné sociální teorii. Praha: SLON.

Sperber, Dan [1996]. Explaining Culture: A Naturalistic Approach. Oxford: Blackwell Publishers.

Spillman, Lyn - Conway, Brian [2007]. Texts, Bodies, and the Memory of Bloody Sunday. Symbolic Interaction 30 (1): 79-103.

Strauss, Anselm [1984]. Social Worlds and Their Segmentation Processes. Studies in Symbolic Interaction 5: 123-139.

Suchman, Lucy [1987]. Plans and Situated Actions: The Problem of Human-Machine Communication. Cambridge: Cambridge University Press.

Suchman, Lucy [2007]. Human-Machine Reconfigurations: Plans and Situated Actions. Cambridge: Cambridge University Press.

Šlesingerová, Eva [2010]. Funes el Memorioso navštěvuje muzeum aneb Vzpomínky na budoucnost. Sociální studia / Social Studies 7 (1): 43-57.

Šmídová, Olga [2010]. Pro nás lépe už bylo... Vymístění z velké historie a kolektivní pamět „českých Němcü“. Sociální studia / Social Studies 7 (1): 59-87.

Šubrt, Jiří [2011]. Kolektivní pamět: Na okraj jedné legendy. Czech Sociological Review 47 (2): 395-407.

Šubrt, Jiří [2015]. O koncepci, která předznamenala teorii rozšířené mysli, a o jejím významu pro sociálněvědní teorii. Sociologický časopis / Czech Sociological Review 51 (4): 697-708.

Šubrt, Jiří - Vinopal, Jiří [2010]. K otázce historického vědomí obyvatel České republiky. Naše společnost 8 (1): 9-20.

Šubrt, Jiří - Vinopal, Jiří [2013]. Historické vědomí obyvatel České republiky perspektivou sociologického výzkumu. Praha: Karolinum. 
Šubrt, Jiří - Maslowski, Nicolas - Lehmann, Štěpánka [2014]. Maurice Halbwachs, koncept rámců paměti a kolektivní paměti. In. Maslowski, Nicolas - Šubrt, Jiří (ed.). Kolektivní pamět: K teoretickým otázkám. Praha: Karolinum, s. 15-30.

Šubrt, Jiří - Vinopal, Jiří - Vávra, Martin [2013]. The Czechs and Their View of History. European Societies 15 (5): 729-752.

Tichá, Jindra [2010]. V odrazu našich vzpomínek. Rodinná amatérská fotografie jako nástroj paměti. Sociální studia / Social Studies 7 (1): 89-100.

Vávra, Martin [2013]. Zdroje, z nichž se vytvářejí představy o historii. In. Šubrt, Jiří - Vinopal, Jiří (ed.). Historické vědomí obyvatel České republiky perspektivou sociologického výzkumu. Praha: Karolinum, s. 39-45.

Wertsch, James V. [1991]. Voices of the Mind. Cambridge, MA: Harvard University Press.

Wertsch, James V. [2002]. Voices of Collective Remembering. Cambridge: Cambridge University Press.

Wright, Peter C. - Fields, Robert E. - Harrison, Michael D. [2000]. Analyzing Human-Computer Interaction as Distributed Cognition: The Resources Model. Human-Computer Interaction 15 (1): 1-41.

Tomáš Karger pưsobí jako vědecký pracovník v Centru výzkumu Fakulty humanitních studii Univerzity Tomáše Bati ve Zlíně. Doktorské studium oboru sociologie absolvoval na Filozofické fakultě Univerzity Palackého v Olomouci obhájením dizertační práce zabývající se etnografickým studiem dynamiky vědění v projektech svobodného softwaru. Právě téma produkce a př̀nosu vědèní predstavuje jednotící badatelský zájem, který uplatňuje při studiu v oblastech technologického vývoje, kolektivní paméti nebo vědeckého poznání. 